$\begin{array}{cl}\text { Türkiye Tarımsal Araştırmalar Dergisi } & \text { Turk J Agric Res } \\ \text { dergipark.gov.tr/tutad } & \text { 2017, 4(2): 124-130 } \\ \text { O TÜTAD } & \text { ISSN: 2148-2306 } \\ \text { e-ISSN: 2528-858X } & \text { doi: 10.19159/tutad.270676 }\end{array}$

\title{
Pitrak (Xanthium strumarium L.) Tohumlarının En Uygun Çimlendirme Metotlarının Belirlenmesi Üzerine Bir Araştırma
}

\author{
Cüneyt CESUR ${ }^{1 *}$, Belgin COŞGE ŞENKAL ${ }^{1}$, Tans u USKUTOĞLU' ${ }^{1}$, Cennet YAMAN", \\ Talat YURTERi² \\ ${ }^{1}$ Bozok Üniversitesi, Ziraat Fakültesi, Tarla Bitkileri Bölümü, Yozgat, TÜRKIYE \\ ${ }^{2}$ Türkiye Tarım Kredi Kooperatifleri, Rize Tarım Kredi Kooperatifi, Rize, TÜRKIYE
}

\begin{abstract}
Geliş Tarihi/Received: 05.12 .2016
Kabul Tarihi/Accepted: 11.04 .2017

*Sorumlu Yazar/Corresponding Author: cuneyt.cesur@bozok.edu.tr

Özet: $\mathrm{Bu}$ çalışma Yozgat il sınırları içerisinde bulunan $1440 \mathrm{~m}$ rakımlı Muslubelen Geçidi'nden 2014 yılı içerisinde toplanan pıtrak (Xanthium strum arium L.) tohumlarının çimlendirilmesinde kullanılabilecek en uygun metodun belirlenmesi amacıyla yapılmıștır. Calıșmada, fark $\mathrm{GA}_{3}(50,250,500,1000,2000 \mathrm{ppm})$ ve sıcaklık (etüvde $90^{\circ} \mathrm{C}$ ve $120^{\circ} \mathrm{C}$ ' de 1,5 ve 10 dakika) muamelesine tabi tutulan pıtrak tohumlarının çimlenme gözlemleri takip edilmiş; 13 farklı uygulamada 10 farklı gözlemle çimlenme süreleri ve oranlarına bakılmıştır. Çimlenme süreleri kontrol, 24 saat 50, 250, 500, 1000 ve $2000 \mathrm{ppm}$ $\mathrm{GA}_{3}$ ile 10 dakika etüvde $90^{\circ} \mathrm{C}$ ve $120^{\circ} \mathrm{C}$ uygulamalarında çimlenme süresi 10 gün olarak tespit edilirken; 1 dakika etüvde $90{ }^{\circ} \mathrm{C}$ ve $120{ }^{\circ} \mathrm{C}$ ( 8 ve 11 . uygulamalar), 5 dakika etüvde $90{ }^{\circ} \mathrm{C}$ ve $120{ }^{\circ} \mathrm{C}$ ( 9 ve 12 . uygulamalar) uygulamalarında ise çimlenme süresi 11 gün olarak tespit edilmiştir. Çalışmada, 13. uygulamada $\left(10 \mathrm{dk}\right.$ etüvde $\left.120^{\circ} \mathrm{C}\right)$ çimlenme süresi 18 gün olarak gerçekleşmiştir. Çimlenme oranları ise 13. uygulamada yaklaşık \% 26 olarak gerçekleşirken, 9. uygulamada (5 dk etüvde $90{ }^{\circ} \mathrm{C}$ ) bu oran $\% 70$ olmuş, diğer uygulamalarda ise pıtrak tohumlarının $\%$ 90-100 arasında çimlendiği tespit edilmiştir.
\end{abstract}

Anahtar Kelimeler: Çimlendirme metotları, pıtrak, Xanthium strumarium L.

\section{A Study on the Determination of Optimum Germination Methods for Cocklebur Seeds (Xanthium strumarium L.)}

\begin{abstract}
This study was carried out to determine the most suitable method for the germination of cocklebur (Xanthium strumarium L.) seeds collected in 2014 from the Muslubelen Pass at $1440 \mathrm{~m}$ in Yozgat province. Cocklebur seeds treated with different $\mathrm{GA}_{3}(50,250,500,1000,2000 \mathrm{ppm})$ and temperature (in the oven $90^{\circ} \mathrm{C}$ and $120^{\circ} \mathrm{C}$ for 1,5 and 10 minutes) and seed germination was observed. Germination times and rates were determined by 10 different observations in 13 different applications. Germination times for $24 \mathrm{~h} \mathrm{GA}_{3}(50,250,500,1000,2000 \mathrm{ppm}), 10 \mathrm{~min}$. in oven $\left(90^{\circ} \mathrm{C}\right.$ and $\left.120^{\circ} \mathrm{C}\right)$ was determined as 10 days, and for $1 \mathrm{~min}$. in oven $90^{\circ} \mathrm{C}$ and $120^{\circ} \mathrm{C}\left(8\right.$ and 11 th application), and $5 \mathrm{~min}$. in oven $90^{\circ} \mathrm{C}$ and $120^{\circ} \mathrm{C}$ ( 9 and 12 th application) germination times determined as 11 days. The germination time in the 13 th application $(10$ min at $120^{\circ} \mathrm{C}$ ) was 18 days. Germination rates of cocklebur seeds were found to be about $26 \%$ in the 13 th application $(10$ min of the plant $\left.120^{\circ} \mathrm{C}\right), 70 \%$ in the 9 th application $\left(5 \mathrm{~min}\right.$. of the plant $90^{\circ} \mathrm{C}$ ) and $90-100 \%$ in other applications.
\end{abstract}

Keywords: Germination methods, cocklebur, Xanthium strumarium L.

\section{Giriş}

Pitrak, Asteraceae familyasina ve Xanthium L. cinsine ait tek y1llık kendine döllenen bir bitkidir. Xanthium strumarium yaklaşı olarak $53^{\circ}$ kuzey $33^{\circ}$ güney enlem dereceleri arasında bulunur (Eymirli ve Torun, 2015). Ilıman bölgelerde yoğun olarak görülmekle birlikte, subtropik ve tropik iklimin hâkim olduğu bölgelerde de rastlanmaktadır (Holm ve ark., 1991). Bitki Kuzey 
Amerika Kitas1 orijinli olup, Kanada'nın güneyinden Amerika Birleşik Devletleri boyunca, Meksika içlerine kadar bir saha anavatanı kabul edilse de; Amerika ve Avrupa kitalarından, Uzak Doğu'ya kadar dünyanın birçok bölgesinde yetişebildiği bildirilmektedir (Lee, 1996; Kim ve ark., 2003). Şekil 1'de görüldüğü gibi Türkiye'nin de 0 (sıfir) metreye yakın sahil bölgeleri olan Akdeniz (Antalya), Ege (İzmir), Marmara (İstanbul, Adapazar1), Karadeniz (Samsun) gibi yörelerinden; Doğu Anadolu (Erzurum, Van, Elazığ), İç Ege'nin yüksek kesimleri (Kütahya, Denizli), Güneydoğu Anadolu (Mardin, Şanlıurfa) ve Orta Anadolu'nun (Yozgat) yüksek kesimlerine kadar birçok bölgesinde her türlü iklim ve toprak şartlarında yetişebilen bir bitkidir.

Türkçe ismi Domuz pitrağı, Siraca otu, Dulavrat otu, Kazık otu, Kaymakam pamuğu gibi isimlerle bilinen türün; İngilizce isimleri "Common cocklebur", "Rough cocklebur", "Clotbur" ve "Ditcbur" ve Çince ismi de "CangEr-Zi”dir (Uluğ ve ark., 1993; Xue ve ark., 2014; Eymirli ve Torun, 2015).

Xanthium L. cinsi ülkemizde 3 tür ( $X$. orientale / domuz pitrağ $1, X$. spinosum / pitrak ve $X$. strumarium / koca pitrak) ve 3 alt tür ( $X$. orientale subsp. italicum / domuz pitrağ $1, X$. strumarium subsp. brasilicum / yitik pitrak ve $X$. strumarium subsp. strumarium / koca pitrak) olmak üzere 6 takson ile temsil edilmektedir (Güner, 2012).

Pıtrak bitkisi deri hastalıkları, baş ağrısı, sinüzit, karaciğer hastalıkları ve kanser gibi birçok hastalığın ve rahatsızlığın tedavisi için geleneksel Çin tıbbında uzun zamandır kullanılmaktadır (Kim ve ark., 2003; Han ve ark., 2007; Xue ve ark., 2014). Üzerinde yapılan diğer birçok çalışmada, bitkide biyoaktif özellikler gösteren bileşikler bulunmuștur. Söz konusu bu bileșiklerin antitümör, antibakteriyel, antifungal (mantar önleyici), antitussif (öksürük giderici), antienflamatuvar (iltihap azaltıcı), analjezik (ağrı kesici), hipoglisemik (kan şekeri düşürücü), antimitotik (hücre çoğalmasını durdurucu), antioksidant ve insektisit (böcek öldürücü) etkilerinin olduğu tespit edilmiștir (Zhang ve Zhang, 2003; Turgut ve ark., 2005; Sarı ve ark. 2010). Ayn1 zamanda bitkinin tohumlarında bulunan yağ ve üretmiș olduğu biyokütle sebebiyle enerji bitkisi olarak da değerlendirilebilmesinden, çalımsı yapıda oluşan yoğun biyokütlesinden çeşitli yap1 malzemeleri üretimine; erozyon, sel, taşkın, toprak kayması gibi çeşitli çevre zararlanmalarını engellemeden, baraj havzalarının 1slahı ve biyoçeşitliliğin gelişmesine kadar çok çeşitli gayelere hizmet edebilme yönü de mevcuttur (Nagel ve ark., 2005; Wei-He ve Cheng-Jiang, 2010; Cheng-Jiang ve ark., 2012; Moore ve ark., 2014)

Bitkisel üretimde temel yetiştiricilik faaliyetlerinde belki de en önemli safha bir tohumun çimlenme performansıdır. Bitkisel üretimde çimlenme süresi ve çimlenme oranının bilinmesi verimliliği önemli ölçüde etkileyen unsurlardır. $\mathrm{Bu}$ sebeple kültürü yapılacak bir bitkinin çimlenme özellikleri bilinerek çoğaltımına yönelik çalışmaların yapılması önem arz etmektedir. Çimlenme süresi bilinmeyen bir tohumun erken ya da geç ekimi, tohum çıkışını olumsuz yönde etkileyebileceği gibi; çimlenme oranının bilinmemesi ekim yapılacak tohumun tarlaya, az ya da çok ekilmesine sebep olacaktır ki, bu da verimliliği ve kaliteyi olumsuz yönde etkileyen hususlardan biridir (Muhyaddin ve

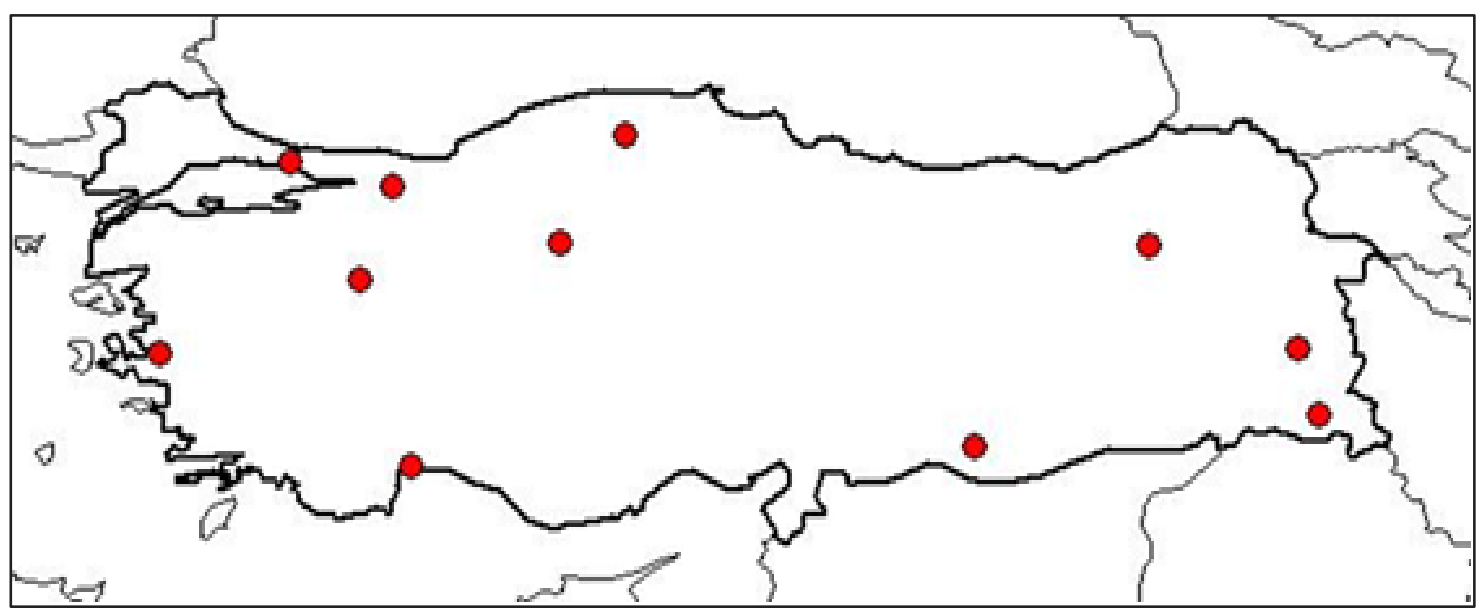

Şekil 1. Pitrak (Xanthium) bitkisinin Türkiye coğrafyasındaki dağılımı (Anonim, 2016) 
Wiebe, 1989). Çimlenme; 1şık, oksijen, sıcaklık ve su gibi temel unsurlara bağlıdır. Ancak bu unsurların yeterli olmasına rağmen bazı bitkilerin tohumlarında, bazı fizyolojik ve morfolojik (dormansi, sert ya da kalın kabukluluk, vb.) engellerden dolayı çimlenme hadisesi oluşmamaktadır (Çetinbaş ve Koyuncu, 2005). Verimli bir çimlenme için dormansi gibi engellerin ortadan kaldırılması gerekir (Martinez-Gomez ve Dicenta, 2001). Bu engellerin tespiti için bazı çimlenme testlerinden faydalanılmaktadır. Çimlenme testleri bakım maliyetlerinin azaltılması, sağliklı bir bitki dokusu sağlanması, kanunî çevre uyumu ve çevre kalitesi, kısa sürede yoğun bir bitki örtüsünün oluşturulmas1, farklı bölge ve ekolojilerden gelen tohum materyallerinin teknik özelliklerinin kısa sürede tespiti için çok mühim katkılar sağlar (Atik ve ark., 2007).

Tohumun çimlenmesini olumsuz etkileyen çevresel unsurların tesirini; katlama, osmotik tohum uygulamaları polyethyleneglycol (PEG), giberellik asit (GA), indol butirik asit (IBA), absisik asit (ABA) tohumların soğuklukla muamelesi, değişik potasyum nitrat uygulamaları, sülfirik as it $\left(\mathrm{H}_{2} \mathrm{SO}_{4}\right)$, potasyum hidroksit $(\mathrm{KOH})$, sıcaklık muameleleri gibi değişik uygulamalar yaparak gidermek mümkündür (Hartman ve ark., 1990; Y1ldız ve Eti, 1995; Khattak ve ark., 2001; Wazir ve ark, 2001; Karakurt ve ark., 2010). Bu uygulamalarla tohumlarda fizyolojik, biyolojik ve morfolojik değişimler meydana getirerek, tohumda çimlenmeyi teşvik eden maddelerin ortaya çıtığı ve çimlenmeyi engelleyicilerin giderilerek tohumun çimlenme olgunluğuna ulaşması mümkün olabilmektedir (Mayer ve Mayber, 1963; Atwater, 1980; Köse, 1997; Duman, 2002).

$\mathrm{Bu}$ çalışma; pitrak tohumlarına farklı çimlendirme yöntemleri uygulanarak, tohumun en uygun çimlenme süresive çimlenme oranı tespit edilerek, kültürünün yapılması durumunda sağliklı bir veri tabanına göre bitkisel üretim faaliyetlerini yürütmek amacıyla yapılmıştır.

\section{Materyal ve Yöntem}

Çalışmada kullanılan pitrak (Xanthium strumarium L.) tohumları; 2014 yılı sonbaharında, Yozgat ili sınırları içerisinde bulunan $1440 \mathrm{~m}$ rakımlı Muslubelen Geçidi doğal florasından toplanan ve Bozok Üniversitesi Ziraat Fakültesi'ne bağlı Topçu Deneme İstasyonu'nda ekimi yapilan bitkilerin, 2015 yılında hasat edilen tohumlarından elde edilmiştir (Şekil 2). Toplanan tohumların canlı olup olmadığının tespiti için tetrazolyum testine tabi tutulmuş canlı olduğu tespit edilen tohumlar ile çalışmaya başlanmıştır.

Çimlenme süresi ekimin yapıldığ1 ilk günden, çimlenmenin görüldüğü ilk güne kadarki olan gün sayıs1 hesaplanarak tespit edilirken; çimlenme oranı ilk çimlenmeden sonra alınan 11 gözlem sonrasındaki ulaşılan toplam çimlenen bitki sayısı, toplam ekilen tohum sayısina oranlanarak belirlenmiştir. Çimlenme enerjisi (hızl) ise, 25.03.2016 tarihinde ekimden sonraki 10. günde (04.04.2016) çıkış gösteren bitki sayıları sayılarak toplam ekilen tohum sayısina oranlanarak bulunmuştur. Çimlenme denemesi tesadüf parselleri deneme desenine göre 3 tekerrürlü ve her tekerrürde 10 tohum olacak şekilde yürütülmüştür. Çalışmada, aşağıda belirtilen 13 farklı çimlenme uygulaması yapılmıştır:
a. Kontrol
b. 24 saat $50 \mathrm{ppm} \mathrm{GA}_{3}$
c. 24 saat $250 \mathrm{ppm} \mathrm{GA}_{3}$
d. 24 saat $500 \mathrm{ppm} \mathrm{GA}_{3}$
e. 24 saat $1000 \mathrm{ppm} \mathrm{GA}_{3}$
f. 24 saat $1500 \mathrm{ppm} \mathrm{GA}_{3}$
g. 24 saat $2000 \mathrm{ppm} \mathrm{GA}_{3}$
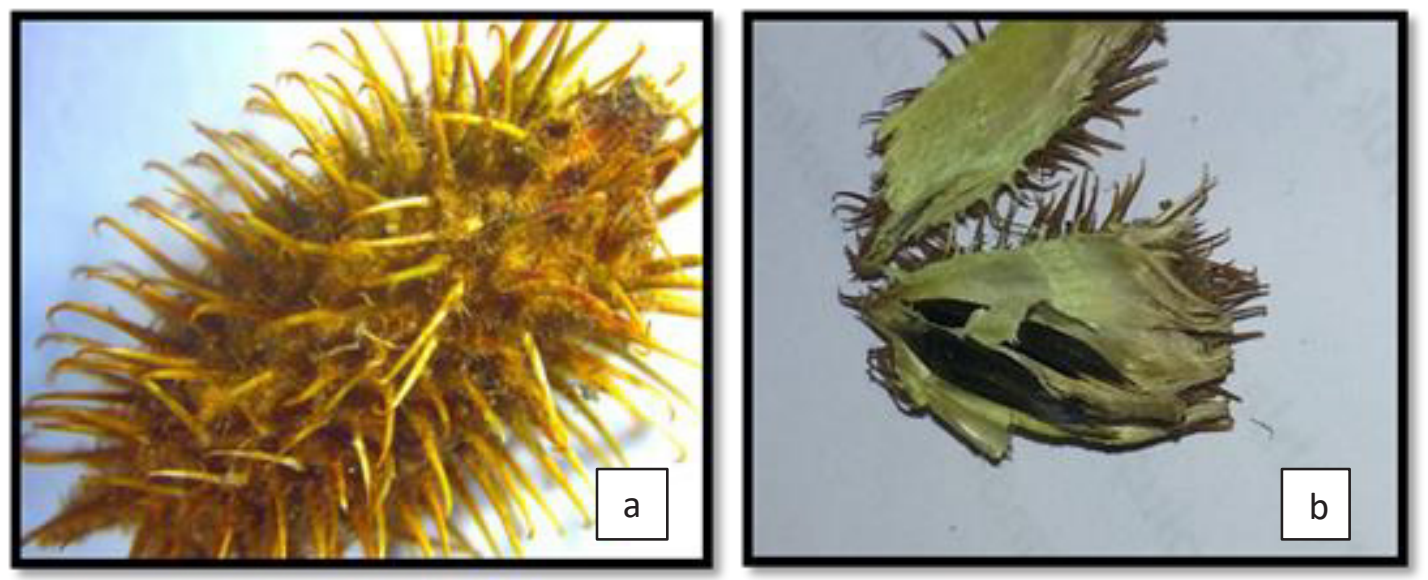

Şekil 2. Pitrak bitkisinin meyvesi (a) ve tohumu (b) 
h. $1 \mathrm{dk}$ etüvde $90{ }^{\circ} \mathrm{C}$

i. $5 \mathrm{dk}$ etüvde $90{ }^{\circ} \mathrm{C}$

j. $10 \mathrm{dk}$ etüvde $90^{\circ} \mathrm{C}$

k. $1 \mathrm{dk}$ etüvde $120^{\circ} \mathrm{C}$

1. $5 \mathrm{dk}$ etüvde $120^{\circ} \mathrm{C}$

m. $10 \mathrm{dk}$ etüvde $120^{\circ} \mathrm{C}$

Uygulamalar arasindaki farklılıklar asgari önemli fark (A.Ö.F) ile belirlenmiştir. İstatistikî analizler TARIST paket programı ile yapılmıştır.

\section{Bulgular ve Tartış ma}

Tohumlara uygulanan, tetrazolyum testi neticesi tohumların canlılı oranının yüzde yüze yakın olduğu tespit edilmiştir. Pitrak bitkisine uygulanan çimlenme testlerinin varyans analizi neticesinde çimlenme oranı üzerine uygulamaların istatistiki olarak \% 1 düzeyinde önemli olduğu görülmüştür (Tablo 1). Tablo 2'den görüldüğü gibi, toplam 13 uygulamanın ilk on iki uygulamas nnda çimlenme süreleri kontrol dâhil 10 gün olarak tespit edilirken, 13. uygulama olan etüvde $120{ }^{\circ} \mathrm{C}$ 'de 10 dakika bekletilen pıtrak tohumlarının çıkış süresi 18 gün olarak tespit edilmiştir. $\mathrm{Bu}$ bulgulardan anlaşılacağ1 üzere pitrak tohumlarının çimlenme süresi $\mathrm{GA}_{3}$ ile yapılan farklı dozlardan ve etüvde sicaklık uygulamalarının $90{ }^{\circ} \mathrm{C}$ 'de 1,5 ve 10 dakika; $120{ }^{\circ} \mathrm{C}^{\prime}$ lik 1 ve 5 dakikalik bekletmelerden etkilenmediği, ancaketüvde $120^{\circ} \mathrm{C}^{\prime}$ lik sicaklıkta
10 dakikalık bekletmeden olumsuz etkilendiği ve çimlenme süresinin diğer uygulamalara göre 8 gün geciktiği görülmektedir. $\mathrm{Bu}$ verilerden sıcaklık uygulamasının derecesi ve süresinin artması pitrak tohumunda strese sebep olduğu anlaşılmaktadır. Aynı zamanda $120{ }^{\circ} \mathrm{C}$ 'de 10 dakika bekletilen tohumların çimlenme süresinin uzamasina rağmen çimlenmesi, bu bitkinin sıcaklıklara oldukça dayanıklı olduğunu da göstermektedir.

Yine Tablo 2'de görüldüğü üzere; çimlenme enerjisi kontrol ekiminde \% 57 olarak tespit edilirken, $\mathrm{GA}_{3}$ uygulamalarında en yüksek çimlenme enerjisi \% 77 ile 6. uygulama olan 24 saat $1500 \mathrm{ppm}^{\mathrm{GA}_{3}}$ ve 24 saat $50 \mathrm{ppm} \mathrm{GA}_{3}$ uygulamalarından elde edilmiştir. $\mathrm{GA}_{3}$ dozlarında en düşük çimlenme enerjisi ise 24 saat 500 ppm $\mathrm{GA}_{3}$ uygulamas indan \% 43 olarak elde edilmiştir.

Etüvde sıcaklık uygulamalarından elde edilen çimlenme enerjisinin $\mathrm{GA}_{3}$ uygulamalarına göre daha düşük çıktığı görülmektedir. Sicaklık uygulamalarında en yüksek çimlenme enerjisi $1 \mathrm{dk}$ etüvde $90 \quad{ }^{\circ} \mathrm{C} \quad$ ve $5 \mathrm{dk}$. etüvde $120{ }^{\circ} \mathrm{C}$ uygulamalarında \% 67 olarak tespit edilirken, $5 \mathrm{dk}$. etüvde $90{ }^{\circ} \mathrm{C}$ uygulamasındaki çimlenme enerjisi ise \% 30 ile en düşük oranda gerçekleşmiştir. 10 $\mathrm{dk}$. etüvde $120{ }^{\circ} \mathrm{C}$ uygulamasinda ise $\% 0$ olarak kaydedilmiştir. Çimlenme enerjisi $\% \quad 0$ olarak tespit edilen uygulamada çimlenme oranı da diğer

Tablo 1. Pitrak tohumlarının çimlenme oranına ait varyans analiz tablosu

\begin{tabular}{lcccccc}
\hline $\begin{array}{l}\text { Varyasyon } \\
\text { kaynağ }\end{array}$ & $\begin{array}{c}\text { Serbestlik } \\
\text { derecesi }\end{array}$ & $\begin{array}{c}\text { Kareler } \\
\text { toplam1 }\end{array}$ & $\begin{array}{c}\text { Kareler } \\
\text { ortalamas }\end{array}$ & Hesaplanan F & \multicolumn{2}{c}{ F tablo değeri } \\
\cline { 5 - 7 } Tekerrür & 2 & 0.154 & 0.077 & $0.409^{\text {ns }}$ & 3.400 & 5.610 \\
Uygulamalar & 12 & 137.641 & 11.470 & $61.000^{* *}$ & 2.180 & 3.030 \\
Hata & 24 & 4.513 & 0.188 & & & \\
Genel & 38 & 142.308 & 3.745 & & & \\
\hline
\end{tabular}

ns: İstatistiki açıdan önemsiz, ${ }^{* *}: \% 1$ düzeyinde önemli

Tablo 2. Pıtrak tohumlarının çimlenme süresi ve çimlenme oranlarına bazı uygulamaların tesiri

\begin{tabular}{|c|c|c|c|c|}
\hline Uy gulama no & Uygulamalar & $\begin{array}{c}\text { Çimlenme süresi } \\
\text { (Gün) }\end{array}$ & $\begin{array}{c}\text { Çimlenme oran1 } \\
(\%)^{*}\end{array}$ & $\begin{array}{c}\text { Çimlenme enerjisi } \\
(\%)\end{array}$ \\
\hline 1 & Kontrol & 10 & $93 \mathrm{ab}$ & 57 \\
\hline 2 & 24 Saat $50 \mathrm{ppm} \mathrm{GA}_{3}$ & 10 & $93 \mathrm{ab}$ & 77 \\
\hline 3 & 24 Saat $250 \mathrm{ppm} \mathrm{GA}_{3}$ & 10 & $96 \mathrm{ab}$ & 73 \\
\hline 4 & 24 Saat $500 \mathrm{ppm} \mathrm{GA}_{3}$ & 10 & $96 \mathrm{ab}$ & 43 \\
\hline 5 & 24 Saat $1000 \mathrm{ppm} \mathrm{GA}$ & 10 & $90 \mathrm{~b}$ & 50 \\
\hline 6 & 24 Saat $1500 \mathrm{ppm} \mathrm{GA}_{3}$ & 10 & $100 \mathrm{a}$ & 77 \\
\hline 7 & 24 Saat $2000 \mathrm{ppm} \mathrm{GA}_{3}$ & 10 & $90 \mathrm{~b}$ & 60 \\
\hline 8 & $1 \mathrm{Dk}$ Etüvde $90^{\circ} \mathrm{C}$ & 11 & $90 \mathrm{~b}$ & 67 \\
\hline 9 & 5 Dk Etüvde $90^{\circ} \mathrm{C}$ & 11 & $70 \mathrm{c}$ & 30 \\
\hline 10 & 10 Dk Etüvde $90{ }^{\circ} \mathrm{C}$ & 10 & $96 a b$ & 47 \\
\hline 11 & $1 \mathrm{Dk}$ Etüvde $120^{\circ} \mathrm{C}$ & 11 & $90 \mathrm{~b}$ & 47 \\
\hline 12 & 5 Dk Etüvde $120^{\circ} \mathrm{C}$ & 11 & $96 \mathrm{ab}$ & 67 \\
\hline 13 & 10 Dk Etüvde $120^{\circ} \mathrm{C}$ & 18 & $26 \mathrm{~d}$ & 0 \\
\hline
\end{tabular}

*: Aynı harfle gösterilen değerler arasında farklılıklar istatistiki olarak \% 5 düzeyinde önemsizdir. 
uygulamalara göre en düşük seviye \% 26 olarak tes pit edilmiştir.

Şekil 3'ten pitrak tohumlarına yapılan $\mathrm{GA}_{3}$ ve sıcaklık uygulamaları mukayese edildiğinde $\mathrm{GA}_{3}$ uygulamalarında çimlenme enerjisinin daha yüksek çıktığı görülmektedir.

$\mathrm{Bu}$ bulgulara göre sicaklık uygulamasının, Şekil 4'ten de görüleceği üzere, pitrak tohumlarının çimlenme enerjisinde strese sebep olduğunu söylemek mümkündür. Uygulamaların çimlenme oranlarına etkisine bakıldığında; 13. uygulamanın çimlenme oranı $\% 26$ ve 9. uygulamanın çimlenme oran1 ise \% 70 olarak tespit edilirken, kalan diğer uygulamaların çimlenme oranları \% 90-96 aralığında oluşmuştur. $\mathrm{Bu}$ sonuçlara göre sicaklık uygulaması bitkinin çimlenme hızında stres oluşturmasına rağmen 11 . gözlemlerden elde edilen çimlenme oranlarına göre $\mathrm{GA}_{3}$ uygulamaları ile sıcaklık uygulamaları paralellik arz etmektedir. $\mathrm{Bu}$ bulgulara göre sıcaklık uygulamaları pitrak tohumlarının çimlenme süresine ve çimlenme enerjisine stres oluştursa bile, çimlenme oranı üzerinde çok fazla olumsuz bir tesiri görülmemiştir.

Araştırma sonucunda elde edilen bulgular tohumlara yapılan bazı ön işlemlerin tohumların çimlenmelerine etki ettiğini belirten görüşlerle uyum içindedir (Karam ve Al Salem, 2001; Onursal ve Gözlekçi, 2007). Bu etki olumlu olabileceği gibi bazen de olumsuz olabilmektedir. $\mathrm{Bu}$ durum bitkilerin genetik özelliklerine göre değişim göstermektedir. Herhangi bir ön işlem bazı bitkilerin çimlenmesini teşvik ederken, bazı

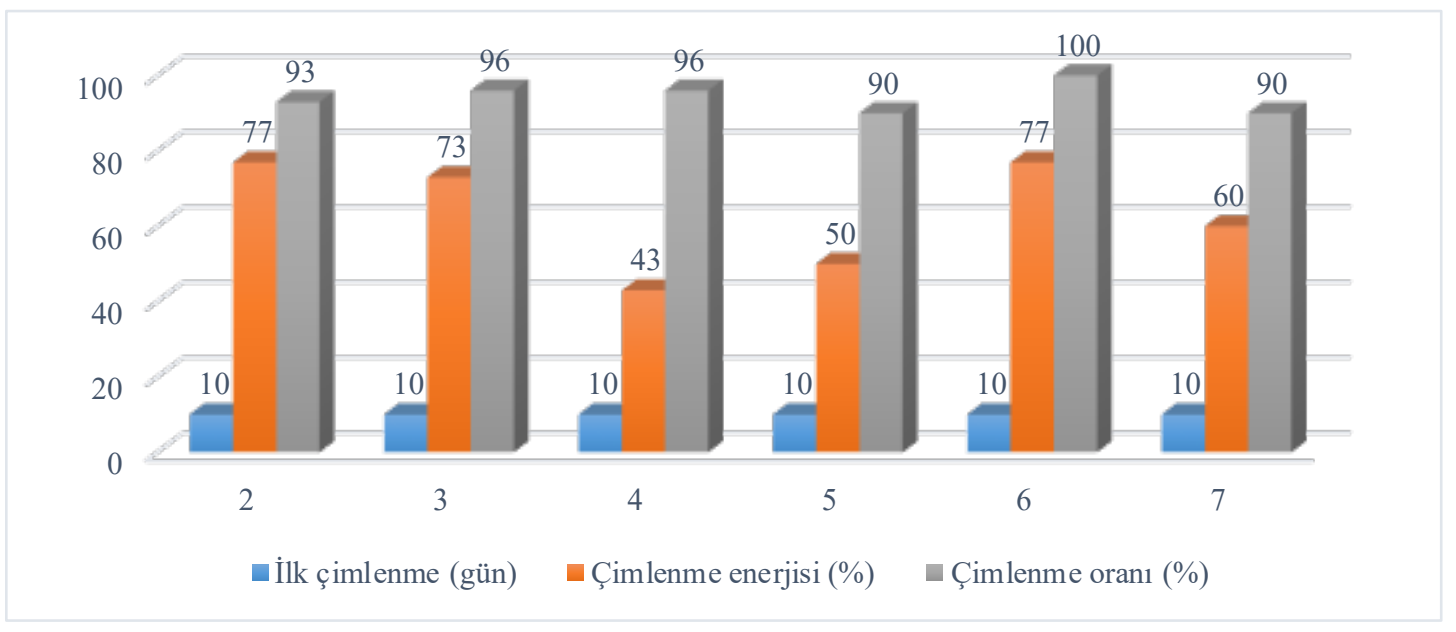

Şekil 3. GA3 uygulamas ının pitrak (X. strumarium) tohumlarının çimlenmes ine etkileri

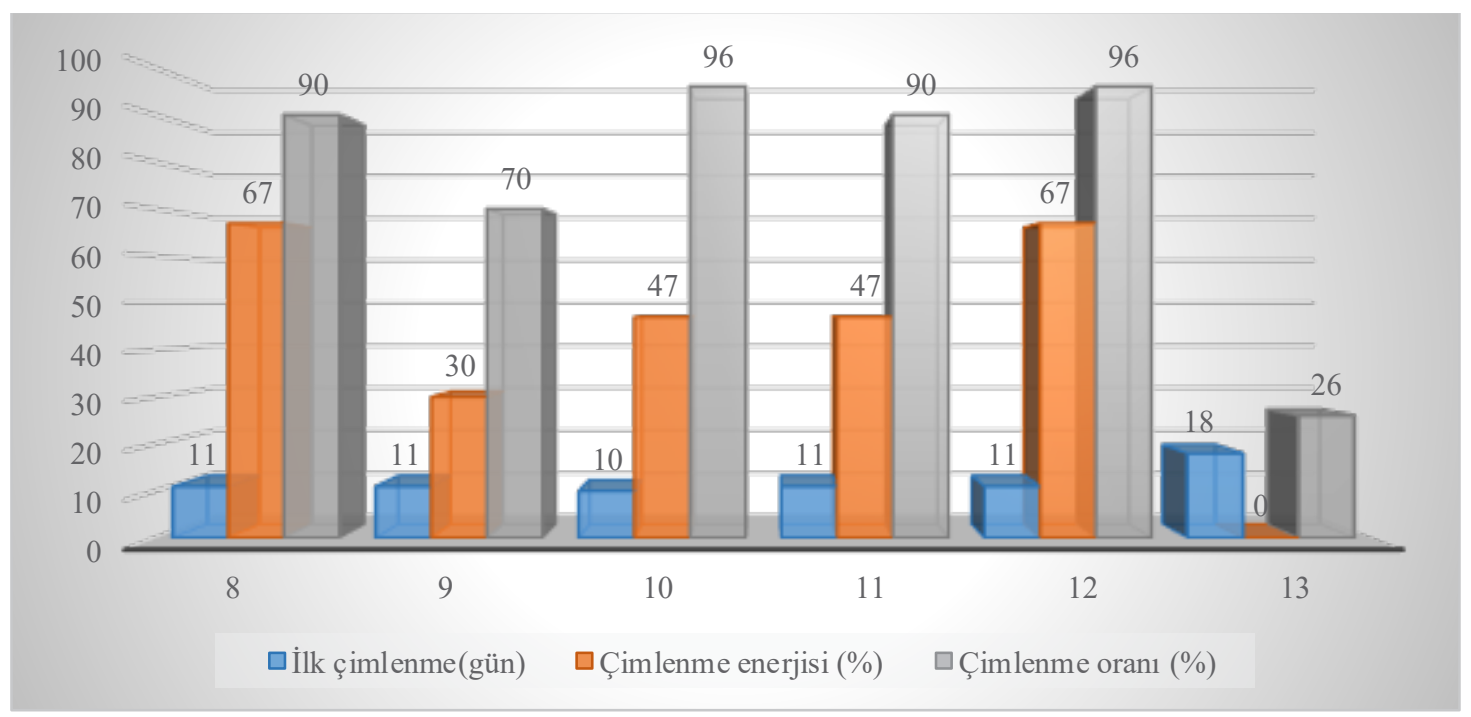

Şekil 4. Sıcaklık uygulamasının pıtrak (X. strumarium) tohumlarının çimlenmes ine etkileri 
bitkilerin de çimlenmesini engelleyebilmekte ya da geciktirebilmektedir (Kenanoğlu ve ark., 2007). Bu bulgularımız; Özvardar ve Özçağıran (1991), Gürbüz ve Gümüşçü (1996), Li ve ark. (2014)'nın çalışmaları ile benzerlik göstermektedir.

\section{Sonuçlar}

Tetrazolyum testi uygulayarak \% $\quad 100$ canlı olduğunu gözlemlediğimiz pitrak tohumları üzerinde yapmış olduğumuz çimlendirme çalışmasında farklı $\mathrm{GA}_{3}$ ve sicaklık uygulamalarının istatistiki olarak $\% 1$ oranında önemli olduğu görülmüştür.

$\mathrm{GA}_{3}$ uygulamalarının çimlenme sürelerine ve oranlarına önemli etkileri görülmezken çimlenme enerjisi üzerinde doğrusal olmayan bir etkisi olduğu belirlenmiştir. $1500 \mathrm{ppm}$ ve $50 \mathrm{ppm}$ uygulamalarında çimlenme enerjisi ( $\%$ 77) aynı etkide bulunurken, 500 ppm'de (\% 43) daha düşük bir çimlenme enerjisi tespit edilmiştir.

Sicaklik derecesi ve süresinin pitrak tohumlarının çimlenme oranına etkisi ise derece ve sürenin artmasıyla olumsuz olmuştur. Ancak süre ve derecenin artmasina rağmen uzun sürede ve düşük yüzde de olsa da çimlenmenin meydana gelmesi pitrak tohumlarının sicaklığa önemli derecede dayanıklı olduğunu göstermiştir. Aynı zamanda sıcaklık derece ve süre artışı bitkinin morfolojisinde stres oluşturduğu gözlenirken, sicaklık derece ve süresinden çimlenme enerjisinin etkilenmesi ise değişken bir seyir izlediği gözlenmiştir.

\section{Kaynaklar}

Anonim, 2016. Türkiye Bitkileri Veri Servisi (TÜBIVES). http://www.tubives.com (Erişim tarihi: 11.11.2016).

Atik, M., Karagüzel, O., Ersoy, S., 2007. Sicaklığın Dalbergia sissoo tohumlarının çimlenme özelliklerine etkisi. Akdeniz Üniversitesi Ziraat Fakültesi Dergisi, 20(2): 203-210.

Atwater, B.R., 1980. Germination, dormancy and morphology of the seeds of herbaceous ornamental plants. Seed Science and Technology, 8(4): 523-573.

Cheng-Jiang, R., Wei-He, X., Silva, J.A.T., 2012. Potential of five plants growing on unproductive agricultural lands as biodiesel resources. Renewable Energy, 41(1): 191-199.

Çetinbaş, M., Koyuncu, F., 2005. Soğukta nemli katlama ve tohum kabuğunun kuş kirazı (Prunus avium L.) tohumlarında dormansinin kırılması üzerine etkileri. Akdeniz Üniversitesi Ziraat Fakültesi Dergisi, 18(3): $417-423$

Duman, İ., 2002. Soğan (Allium cepa L.) tohumlarının çimlenmesini iyileştirici farklı osmotik uygulama yöntemlerinin karșılaștırılması. Ege Üniversitesi Ziraat Fakültesi Dergisi, 39(2): 1-8.
Eymirli, S., Torun, H., 2015. Xanthium strumarium, Türkiye İstilacı Bitkiler Kataloğu. T.C. Gıda, Tarım ve Hayvancılık Bakanlığı, Tarımsal Araștırmalar ve Politikalar Genel Müdürlüğü, Bitki Sağlı̆g Araştırmaları Daire Başkanlığı, Ankara.

Güner, A., 2012. Türkiye Bitkileri Listesi (Damarlı Bitkiler). Nezahat Gökyiğit Botanik Bahçesi Yay inları, Flora Dizisi-1, İstanbul.

Gürbüz, B., Gümüşçü, A., 1996. Farklı gibberellik asit dozları ve uygulama sürelerinin yönlü yüksük otu (Digitalis lanata Ehrh.) tohumlarının çimlenmesine etkileri. Tarım Bilimleri Dergisi, 2(3): 17-20.

Han, T., Li, H.L., Zhang, Q.Y., Han, P., Zheng, H.C., Rahman, K., Qin, L.P., 2007. Bioactivity-guided fractionation for anti-inflammatory and analgesic properties and constituents of Xanthium strumarium. Phytomedicine, 14(12): 825-829.

Hartmann, H.T., Kester, D.E., Davies, F.T., 1990. Plant Propagation Principles and Practices. 5th Ed. Printice Hall. Inc., Englewood Cliffs, New Jersey, USA.

Holm, L.G., Plunknett, D.L., Pancho, J.V., Herberger J.P, 1991. The World's Worst Weeds. Distribution and Biology. Krieger Publishing Company, Malabar, Florida. USA.

Karakurt, H., Aslantaș, R., Eşitken, A., 2010. Tohum çimlenmesi ve bitki büyümesi üzerinde etkili olan çevresel faktörler ve bazı ön uygulamalar. Uludağ Üniversitesi Ziraat Fakültesi Dergisi, 24(2): 115128.

Karam, N.S., Al-Salem, M.M., 2001. Breaking dormancy in Arbutus andrachna L. seeds by stratification and gibberellic acid. Seed Science and Technology, 29(1): 1-56.

Kenanoğlu, B.B., Demir, I., Mavi, K., Yetișir, H., 2007. Lagenaria siceraria genotiplerinin düşük sıcaklıkta çimlenmesi üzerine ekim öncesi uygulamaların etkisi. Tarm Bilimleri Dergisi, 13(3): 169-175.

Khattak, M.S., Wahab, F., Iqbal, J., Rafiq, M., Amin, M., 2001. IBA promotes rooting in the hardwood cuttings of olive (Olea europaea L.) Cultivars. Pakistan Journal of Biological Sciences, 4(6): 633634.

Kim, Y.S., Kim, J.S., Park, S.H., Choi, S.U., Lee, C.O., Kim, S.K., Kim, Y.K., Kim, S.H., Ryu, S.Y., 2003. Two cytotoxic sesquiterpene lactones from the leaves of Xanthium strumarium and their in vitro inhibitory activity on farnesyltransferase. Planta Medica, 69(4): 375-377.

Köse, H., 1997. Ege Bölgesi'nde doğal olarak yetişen baz1 süs ağaç, ağaççı ve çalı tohumlarının çimlendirme yöntemleri üzerinde araştırmalar. Doktora tezi, Ege Üniversitesi Fen Bilimleri Enstitüsü, İzmir.

Lee, J.M., 1996. Common Cocklebur (Xanthium strumarium L.). Iowa State University, The ISU Weed Biology Library, Agronomy No: 517, USA.

Li, C., Chen, F., Zhang, Y., 2014. GA3 and other signal regulators (MeJA and IAA) improve xanthumin biosynthesis in different manners in Xanthium strumarium L. Molecules, 19(9): 12898-12908. 
Martínez-Gómez, P., Dicenta, F., 2001. Mechanisms of dormancy in seeds of peach [Prunus persica (L.) Batsch] Cv. GF 305. Scienta Horticulturae, 91(1-2): 51-58.

Mayer, A.M., Mayber, A.P., 1963. The Germination of Seeds. Vol. 3, The Macmillan Comp., New York.

Moore, J.E., Wolfe, J.D., Franklin, S.B., 2014. Growth responses of different aged individuals of Xanthium strumarium L. in flooded conditions. Journal of The Torrey Botanical Society, 141(1): 72-79.

Muhyaddin, T., Wiebe, H.J., 1989. Effect of seed treatments with polyethylene glycol (PEG) on emergence of vegetable crops. Seed Science and Technology, 17: 49-56.

Nagel, J.M., Wang, X.Z., Lewis, J.D., Fung, H.A., Tissue, D.T., Griffin, K.L., 2005. Atmospheric CO2 enrichment alters energy assimilation, investment and allocation in Xanthium strumarium. Journal New Phytologist, 166(2): 513-523.

Onursal, C.E., Gözlekçi, Ş., 2007. Sandal ağacı (Arbutus andrachne L.) tohumlarına yapilan bazı ön uygulamaların tohum çimlenme oranı ve süresi üzerine etkileri. Akdeniz Üniversitesi Ziraat Fakültesi Dergisi, 20(2): 211-218.

Özvardar, S., Özçağıran, R., 1991. Değişik katlama sıcaklıkları ve katlama öncesi işlemlerin erik tohumlarının çimlenmelerine etkileri. Türkiye 1 . Fidancllik Sempozyumu, Bildiriler Kitab1, 26-28 Ekim, Tokat, s. 319-324.

Sarı, A.O., Oğuz, B., Bilgiç, A., Tort, N., Güvensen, A., Şenol, S.G., 2010. Ege ve Güney Marmara
Bölgeleri'nde halk ilacı olarak kullanılan bitkiler. Anadolu, 20(2): 1-21.

Turgut, M., Alhan, C.C., Gürgöze, M., Kurt, A., Doğan, Y., Tekatli, M., Akpolat, N., Aygün, A.D., 2005. Carboxyatractyloside poisoning in humans. Annals of Tropical Paediatrics, 25(2): 125-134.

Uluğ, E., Kadıŏlu, I., Üremiş, I., 1993. Türkiye'nin Yabancı Otları ve Bazı Özellikleri. T.C. Tarım ve Köyişleri Bakanlığ, Zirai Mücadele Araştırma Enstitüsü Müdürlüğ̈̈, Yayın No: 78, Adana.

Wazir, L., Ali, N., Rahman, N., 2001. Effect of different concentrations of indole butyric acid (IBA) and different soil media on the rootings of olive cuttings. Sarhad Journal of Agriculturae, 17(4): 553-556.

Wei-He, X., Cheng-Jiang, R., 2010. Oil contents and relative components of fatty acid in the seeds of five energy plants. Renewable Energy Resources, 28(2): 62-66.

Xue, L.M., Zhang, Q.Y., Han, P., Jiang, Y.P., Yan, R.D., Wang, Y., Rahman, K., Jia, M., Han, T., PingQin, L., 2014. Hepatotoxic constituents and toxicological mechanism of Xanthium strumarium L. Fruits. Journal of Ethnopharmacology, 152(2): 272-282.

Yıldız, A., Eti, S., 1995. Keçiboynuzu tohumlarının değişik yöntemlerle çimlendirilmesi üzerine araştırmalar. Türkiye II Ulusal Bahçe Bitkileri Kongresi, 3-6 Ekim, Adana, s. 756-760.

Zhang, X.M., Zhang, Z., 2003. The study of intoxication and toxicity of fructus Xanthii. Journal of Chinese Integrative Medicine, 1(1): 71-74. 